\title{
CANINE TRYPANOSOMIASIS: ETIOLOGY OF INFECTION AND IMPLICATIONS FOR PUBLIC HEALTH
}

\section{Eloy LJ (1), Lucheis SB (1, 2)}

(1) Department of Tropical Diseases and Imaging Diagnosis, Botucatu Medical School, São Paulo State University, UNESP, Botucatu, São Paulo State, Brazil; (2) São Paulo Agency of Agrobusiness Technology, APTA, Bauru, São Paulo State, Brazil.

ABSTRACT: Canine trypanosomiasis, caused by protozoans of the genus Trypanosoma, is divided into two primary types: the American form (Chagas disease), due to Trypanosoma cruzi infection, and the African form (sleeping sickness or surra), provoked by Trypanosoma evansi. This disease was originally enzootic and affected only wild animals, including mammals and birds, which served as reservoirs. Later, it spread to domestic animals such as horses, cattle and dogs. The disease became a zoonosis when contact between rural inhabitants and natural Trypanosoma foci occurred, due to ecological imbalances and increasing migration. Dogs are significantly involved in this context, because they are the main domestic animals and participate in the transmission and maintenance cycles of these parasites. This article reports etiological, epidemiological and public health aspects of canine trypanosomiasis, and the most important peculiarities of this zoonosis in dogs.

KEY WORDS: canine trypanosomiasis, Trypanosoma cruzi, Trypanosoma evansi, Chagas disease, surra.

CONFLICTS OF INTEREST: There is no conflict.

\section{CORRESPONDENCE TO:}

SIMONE BALDINI LUCHEIS, Rodovia Marechal Rondon, km 279, caixa postal 108, 18.650-970, São Manuel, SP, Brasil. Phone: +55 149146 3999, +55 1432033257. Email: silucheis@apta.sp.gov.br. 


\section{INTRODUCTION}

Trypanosomiasis or canine trypanosomiasis comes in two main forms: American trypanosomiasis (Chagas disease) caused by Trypanosoma cruzi (T. cruzi), and African trypanosomiasis (surra or sleeping sickness) caused by Trypanosoma evansi (T. evansi) (1).

Trypanosomiasis was originally an enzootic disease circulating in wild animals such as mammals and birds, which served as reservoirs. The disease became a zoonosis due to contact between rural inhabitants and natural foci, resulting from ecological imbalance $(2,3)$.

The spread of Chagas disease in Latin American populations accompanied human migration in the last three centuries, as humans invaded natural areas inhabited by triatomine species, commonly known as "kissing bugs" (4). In 1996, Maywald et al. (5) diagnosed a dog as positive for $T$. cruzi with acute natural infection in the rural zone of a municipal area in Uberlândia, Brazil.

Recently, trypanosomiasis has become urbanized due to increased migration into cities and increases in the number of blood transfusions (3).

Human trypanosomiasis, caused by $T$. cruzi, is the fourth largest endemic disease in the Americas, affecting between 16 and 18 million people, with another 100 million at risk (3). Both the human and canine forms of the disease are concentrated in rural zones and poorer urban areas, where the proliferation of triatomines is easy because of the poor social conditions, such as poor quality housing and the semi-rural aspects of peripheral areas around many cities $(4,6)$.

According to Josh (7), until a short time ago, humans were considered resistant to infection by $T$. evansi; the first case of human infection was reported in an Indian farmer and was considered cured after six months treatment with suramin $(8,9)$.

The importance of dogs in this context is related to the fact that they are the main domestic animals, living in close proximity to humans, and are within the transmission and maintenance cycles of these parasites (9).

Dogs can develop pathological alterations similar to those detected in man and they are considered the experimental model of choice for human Chagas disease (10, 11). 


\section{REVIEW OF THE LITERATURE}

\section{Etiology and Epidemiology}

While studying malaria in Lassance, Minas Gerais state, Brazil, in 1908, Carlos Chagas discovered many flagellate parasites in triatomine intestines and noted that these parasites had the morphological characteristics of trypanosomatids. After subjecting monkeys to bites from these insects, he observed trypanosomes in the peripheral blood of one animal and christened the parasite Trypanosoma cruzi. He later found the same parasite in a child's blood and demonstrated that it was the cause of a very common endemic disease in the central regions of the Brazilian territory. This is the only report in the history of medicine in which the etiological agent, its transmitter, and the clinical manifestations of the disease have been described by the same investigator (12).

The first reference to the existence of this endemic disease in Northeast Brazil is also attributed to Carlos Chagas who, in an interview in 1911, reported that the infection was present in the states of Minas Gerais, Goiás, Mato Grosso, southern Bahia, and perhaps São Paulo. Later, trypanosomiasis was detected in the Northeast, especially after a report that triatomines lived in large areas of Bahia, Pernambuco, Sergipe, and Ceará (13). In Ceará, Gavião Gonzaga verified infected triatomines in Cariri and Quixadá in 1921, with the first human cases being detected only in 1942 by xenodiagnosis (14).

Trypanosoma are flagellated parasites belonging to the subphylum Mastigophora, phylum Sarcomastigophora, class Kinetoplastidae, and order Kinetoplastida. The group presents flagella and an organelle recognized by its kinetoplast and DNA condensation (15).

There are various species of trypanosomes that parasitize animals and humans as well; these include T. congolensis, T. vivax, T. equiperdum, T. brucei, T. evansi, T. rangeli, and $T$. cruzi (16).

Domestic dogs are important reservoirs of Trypanosoma cruzi in several American countries $(10,17-19)$. Dogs are also commonly infected with $T$. rangeli, another human parasite, in areas of Latin America that are endemic for this species $(20,21)$. Other trypanosome species of veterinary and economic interest also infect domestic dogs; they include T. brucei brucei and T. congolense, the causative agents of Nagana or a similar disease in Africa and Asia (22-24), as well as T. evansi, the etiological agent of surra and the so-called "mal de cadeiras" outside the African 
continent $(25,26)$. Domestic dogs may also present mixed infections with the trypanosomatids cited above in geographical areas where these species overlap, which can complicate the diagnosis of these pathogens of medical, veterinary, and economic interest when diagnosis is based on routine serological tests (26-29).

In Brazil, two pathogenic species are found in small animals: $T$. evansi (dogs) and $T$. cruzi (dogs and cats) $(30,31)$. Dantas-Torres $(32)$ reported that $T$. rangeli also infects dogs but is not pathogenic.

Natural infection with $T$. cruzi and other trypanosomatids had already been reported in many species of domestic and wild animals. The main reservoirs are wild animals, since the parasite can be found in 150 wild species, including marsupials, foxes, armadillos etc., and the infection rates in some of these species are high (31).

The trypanosome species that infect dogs include $T$. evansi, which presents the salivary form (transmitted by saliva from the vector), and $T$. cruzi, which presents the stercorary form (transmitted by feces from the vector) (9). According to DantasTorres (32), T. rangeli can be transmitted by both saliva and feces. In Brazil, T. cruzi and $T$. rangeli have been detected in naturally infected dogs and marsupials, respectively $(20,33,34)$. The simultaneous presence of these parasites in the same geographic region allows mixed infection in vertebrate and invertebrate hosts (35).

With the unique exception of dourine $T$. equiperdum, which is the cause of a venereal disease, all trypanosomes have arthropod vectors. Trypanosoma evansi, the etiological agent of African trypanosomiasis (also known as surra or sleeping sickness) in equines and bovines, is transmitted by biting flies, mainly tabanides and Stomoxys. In Central and South America, $T$. evansi is also transmitted by vampire bats of the Desmodus rotundus genus, in which the parasites can multiply and survive for a long time (16). Maia da Silva et al. (36) reported the presence of $T$. cruzi and $T$. rangeli in non-vampire bats captured in Mato Grosso do Sul. Vampire bats, such as Desmodus rotundus, are also proven important reservoirs for T. cruzi, due to the ease with which they adapt to human dwellings and their consequent close proximity to humans and dogs (4).

Trypanosoma cruzi is mainly transmitted to humans and domestic animals by triatomines, hematophagic insects generally called "barbeiros" in Brazil, where they are domestic vectors. During or soon after feasting on blood, the vector eliminates the parasite in its feces (37). Generally, the bite causes itching, and the act of scratching facilitates penetration of the infecting metacyclic trypomastigotic form 
contained in the feces into the bite site. T. cruzi can also penetrate the host organism through the mucosa of the eye, nose, and mouth, or through recent skin wounds or cuts. Other transmission mechanisms include blood transfusion, congenital transmission, organ transplant, and even accidental transmission in laboratories (38). Finally, dogs, cats, and wild carnivores can be infected by $T$. cruzi or $T$. evansi by ingesting infected triatomines, the organs of animals killed by trypanosomosis, and infected fresh carcasses, from rodents, from foodstuffs contaminated by kissing bug feces, or from wild animals $(16,38-41)$. The main mode of transmission in canine species seems to be the ingestion of infected vectors $(42,43)$.

Infection with $T$. evansi by the ingestion of blood and infected tissue was experimentally demonstrated in dogs (42). Maywald et al. (5) diagnosed a dog infected with $T$. cruzi, even when triatomines were reported to be absent from the home and surrounding annex buildings (chicken coops and grain stores), suggesting routes of infection other than kissing bug feces; one such route could be the predation of infected mammals.

The prevalence of $T$. cruzi in dogs and cats in endemic areas is higher than the prevalence in humans (31). Montenegro et al. (18) and Souza et al. (11) reported that, in areas where Triatoma infestans is the main domiciliary vector, T. cruzi infection rates are higher in dogs than they are in humans.

Of all the domestic reservoir mammal species, cats and dogs, due to their close proximity to humans, their high susceptibility to chagasic infection, and their ability to attract the vectors, are the most important in maintaining endemicity (44). However, due to cats' habit of spending most of their time outside of the house, dogs are considered the main qualitative and quantitative contributors to the maintenance of disease transmission, mainly in endemic areas; they have been the main blood source for Triatoma infestans and other triatomines, such as Panstrongylus megistus and Rhodnius neglectus, followed by humans and birds $(4,45)$.

Rates of natural infection with $T$. cruzi in dogs vary greatly according to the local epidemiological situation, and they are generally high when there are high triatominetrypanosomic indices from a domicile unit or location. Field studies based on xenodiagnosis throughout Latin America have shown wide variations in the rates of natural infection in dogs, with extremes of $3 \%$ and $60 \%$, and a greater concentration of rates between $8 \%$ and $28 \%$ (46). 
In various localities in Brazil and Argentina, xenodiagnosis has revealed infection rates of more than $20 \%$ in cats and dogs. In the Yaracuy Valley, Venezuela, 70 out of a total of 140 dogs examined were positive by xenodiagnosis. In Chile, 3,321 dogs and 1,805 cats were examined, and $9.1 \%$ and $11.9 \%$, respectively, were found to be positive (30).

Lucheis et al. (34) studied 50 dogs belonging to 30 chronic chagasic individuals in the western region of São Paulo state. These animals underwent artificial xenodiagnosis, hemoculture, and polymerase chain reaction (PCR) for T. cruzi. A total of 43 dogs (86\%) were reactive to at least one of the tests, with $34(68 \%)$ being reactive to xenodiagnosis, $30(60 \%)$ to hemoculture, and $25(50 \%)$ to PCR.

The diagnosis of dogs with Chagas disease and the detection of infected triatomines in a home serve as sentinels for human infection $(31,47)$.

High morbidity and mortality rates are observed in dogs infected with $T$. evansi (42, 48). Horses, followed by dogs, are the species most severely infected by $T$. evansi (42).

In a survey in the Pantanal region of Mato Grosso state, Brazil, Franke et al. (25) found a prevalence of $T$. evansi infection of $30 \%$ in dogs, suggesting that their close contact with horses could make these animals important reservoirs for the parasite in this region.

An unknown Trypanosoma species was isolated from an axenic culture of intact skin from a domestic dog co-infected with Leishmania (Viannia) braziliensis and captured in Rio de Janeiro, Brazil. Giemsa-stained smears of cultures grown in different media revealed the presence of epimastigotes, trypomastigotes, spheromastigotes, transitional stages, and dividing forms (epimastigotes or spheromastigotes). This trypanosome was isolated from the intact skin of the scapular region of a dog, but not from the intact abdominal skin, cutaneous lesions, venous blood, lymph nodes, liver, spleen or heart. This species does not appear to be pathogenic in dogs. It can be easily distinguished from $T$. cruzi by the size of the trypomastigotes and kinetoplasts, in addition to its inability to infect mouse peritoneal macrophages. It can be distinguished from $T$. rangeli by the body width and size of its spheromastigotes. In contrast to $T$. cruzi and $T$. rangeli, this trypanosome was unable to infect triatomines. It was concluded that this isolate is a new Trypanosoma species and the name Trypanosoma caninum was suggested (49). 


\section{CLINICAL MANIFESTATIONS}

\section{Dogs Infected with $T$. cruzi}

Although Brazil is an endemic area for Chagas disease and dogs are recognized as an important reservoir for T. cruzi, most studies with this species are based on experimental inoculations or post-mortem-identified alterations $(11,32)$. Few studies characterize the clinical and laboratory aspects of natural Chagas disease infection in dogs (18).

Dogs constitute the experimental model of choice for chagasic infection in humans, as it is difficult to reproduce this infection in other experimental models (11). They are also the only species capable of developing chronic pathological alterations similar to those detected in humans, and they can present congestive cardiac insufficiency (10).

From the anatomopathological and histopathological points of view, the most important aspect of this model is that it reproduces a form of fibrous chronic chagasic cardiopathy that is very similar to that observed in humans $(50,51)$.

The consequences of $T$. cruzi infection in humans, and the equivalent form in dogs, involve visceral damage (6\%), progressive neurological disturbances (3\%), and cardiac disorders at some point in the infected organism's lifetime (52).

Clinically affected dogs can develop both acute and chronic disease. Chagas infection is characterized by an acute phase, either symptomatic or not, lasting about two months; the disease then evolves to a chronic phase that lasts for the rest of the individual's life and is known as the chronic indeterminate form of Chagas disease (53).

The acute phase can be observed in young dogs between five and six months old. The affected animals develop generalized infection with extensive lesions, mainly in the myocardium and central nervous system. The acute phase is further characterized by anorexia, generalized lymphadenopathy, diarrhea, myocarditis, and sudden death, which can occur due to serious cardiac arrhythmia. It is more difficult to diagnose the acute phase of the disease in adult dogs. The indeterminate chronic form occurs eight to 36 months after initial infection and is characterized by ventricular arrhythmias and myocardial dilation. Signs of cardiac insufficiency are initially seen on the right side, with progression to biventricular insufficiency (54). Many factors have been suggested to explain the pathogenesis and development of chagasic cardiopathy. These include direct destruction of muscle tissue by $T$. cruzi, 
intracardiac nervous system lesions, microangiopathy, and auto-immunity, with fibrosis being one of the most important observed symptoms (53).

Myocarditis in chronic chagasic cardiopathy displays intense diffuse and focal fibrosis, and it is mainly intrafascicular. This fibrosis starts in the endomysium as a substitute for cardiomyocytes, and as scar fibrosis in the resolution of inflammation foci (53).

In a study by Caliari et al. (51), two out of $11 \mathrm{~T}$. cruzi cardiomegalia presented a globular heart, with both ventricles and cardiac chambers dilated, especially the right atrium; hydropericardium was also observed in six dogs. Histopathologically, fibrous chronic chagasic myocarditis was detected by light microscopy in all animals; it was discrete and moderate, and consisted of mononuclear infiltrate. This infiltrate was mainly distributed between normal myocardiocytes, as well as around damaged cells. Collagen fibers were thicker than normal, especially in the perimysium. The endomysium was also thicker, especially in areas that did not have significant myocardiocyte destruction. Amastigote form nests were not seen. Chagasic dogs presented a significant reduction in cardiac muscle and an increase in the area occupied by conjunctive and adipose tissue compared to normal dogs. Two dogs with congestive cardiac insufficiency $(\mathrm{CCl})$ presented a large area with fibrosis.

Rossi (55) observed that the left ventricle and right atrium are the areas most affected by chagasic myocarditis.

In another study with four dogs naturally infected with $T$. cruzi in Mato Grosso do Sul, Souza et al. (11) reported that, as in humans, the intensity of clinical manifestations depend on the animal's age and the type of strain involved in the infection. Fernandes et al. (45) studied dogs of varying ages and observed that symptoms were less severe in much older animals, with discrete depression and anorexia. Therefore, age, ignorance of the period during which the animals were exposed to the agent, and the type of circulating strain can justify the absence of symptoms during physical examination. Despite the absence of verified clinical signs of cardiac insufficiency, increased right ventricle size can be considered an alteration related to T. cruzi infection.

Scalabrini et al. (50) reported that four animals infected by Trypanosoma cruzi had sparsely distributed small foci of interstitial mononuclear inflammation in all sections examined, especially in the atria and upper portions of the interventricular septum; this demonstrates the presence of a disseminated discrete focal myocarditis, a 
reported sign of the indeterminate form of Chagas disease that has been noted in both humans and experimental animals.

In cardiopathy of chagasic etiology, the parasite mainly affects ventricular atrium conduction routes and the branches of the bundle of His, leading to an increased frequency of atrioventricular and extrasystole blocks and branch blocks (11).

Barr et al. (56) found increases in ALT, AST, LDH, urea, and creatinine only in the acute disease phase.

Total protein values were also elevated, and although this does not corroborate with the findings of Barr et al. (56), the hyperproteinemia found in this study could be associated with hypergammaglobulinemia due to antigenic stimulation provoked by the parasite, as seen in canine infections caused by other trypanosomatids (57).

Anemia is a consistent finding in dogs naturally infected with $T$. cruzi or $T$. evansi (48). In an 82-day study of experimental infection in dogs, Aquino (58) detected anemia from the second week of infection; it was macrocytic normochromic between the fifth and the seventh weeks and normocytic normochromic for the remainder of the study period. Various mechanisms have been proposed to explain the still incompletely elucidated origin of anemia in trypanosomiasis; these include suppression of erythropoietic activity due to bone marrow depression, hemodilution, hemolysis resulting from immunological factors, direct parasite action, and the action of products released by the parasites. The reduction in global leukocyte count without alterations in differential count predominates in reports on natural infections, although some authors do not highlight alterations in leukocyte response (48, 59). Experimentally infected dogs displayed leukopenia with neutropenia between the second and the fifth weeks of infection and had values within the normal limits for the remainder of the study period (57).

Hypoglycemia has been shown to be an important clinical laboratory finding in naturally infected animals, and it is inversely proportional to blood trypanosome count. This has not been observed in experimental infection: in such experiments, dogs maintained their glucose levels within normal limits for the whole experimental period (59).

\section{Dogs Infected with $T$. evansi}

Natural infection with $T$. evansi in dogs showing severe clinical signs and even potentially fatal disease levels has been reported in various Brazilian states $(32,48)$. 
Important clinical signs in naturally infected dogs include: intermittent fever, progressive anemia, anorexia, cachexia, edema of the head, pharynx, and limb, lymphadenopathy, rear limb paralysis, ataxia, a lack of coordination, tonic-clonic seizures, opisthotomus, and corneal opacity (42).

In Jaboticabal city, São Paulo state, a case of $T$. evansi infection was described in a dog that had travelled to the Pantanal region. The animal presented a picture of progressive weight loss, apathy, debility, cheek edema, fever $\left(41^{\circ} \mathrm{C}\right)$, urticarial patches all over the body, increased palpable lymph node volume, and abdominal sensitivity (11).

During an outbreak of sleeping sickness in the Pantanal region $T$. evansi infection was detected in four dogs that presented with fever, anemia, conjunctivitis, edema of the limbs and lower parts, progressive weakness, and gradual paresis of the hind limbs (16).

In another report, a dog from southern Mato Grosso seen in São Paulo with a confirmed diagnosis of $T$. evansi trypanosomiasis presented fever, splenomegaly, hyper-colored mucosa, lymphadenomegaly, and moderate cachexia (42).

In Rio Grande do Sul, Franciscato et al. (48) reported weakness, progressive weight loss, and lack of appetite in a naturally infected dog from the periurban zone of Santa Maria. Another two dogs from the rural area of Uruguaiana displayed apathy, fever, pale mucosa, and enlarged submandibular lymph nodes; one of them also presented signs of renal compromise. Disease in these three dogs progressed to death.

In dogs experimentally infected with a strain from the Pantanal, the disease was characterized by intermittent fever, with fever peaks directly related to increases in parasitemia, pale mucosa, progressive weight loss, increased palpable lymph node volume, and edema in the neck, eyelid, and abdominal region (42).

Increased serum protein levels with a reduced albumin/globulin ratio have been reported frequently in various infected hosts. Increased serum total protein in dogs is due to elevated globulin levels and a parallel drop in albumin concentration (48). Electrophoresis has revealed that hyperglobulinemia is caused by increased gamma globulins and reflects the high antibody levels found in infected animals. It has been suggested that the drop in albumin levels on its own is a compensatory mechanism for maintaining blood viscosity, which is increased by hyperglobulinemia (57).

Studies on serum enzymatic activity in experimentally infected dogs revealed increased ALT and AST levels with AST concentration reaching values above those 
considered normal for the species (57). In natural infection, only increased AST levels have been reported. These observed increases in AST could be due to hepatic or muscle tissue lesions (48).

Anatomo-histopathological studies of infection in dogs are scarce. In experimentally infected dogs, Aquino et al. (57) observed lymphadenopathy and splenomegaly in all infected animals. Histology revealed marked hyperplasia of the lymphoid follicle in the spleen and lymph nodes, with macrophage and plasmocyte infiltrate in the paracortical region. In the liver, centrolobular pattern hepatocyte degeneration and mononuclear cell periportal infiltrate were seen in all inoculated dogs.

Reports of CNS lesions in infected dogs are infrequent, contrary to the findings in horses. Experimental infection led to the accumulation of mononuclear cells close to the cerebral cortex meninges and in white and grey matter, even though animals did not present neurological symptoms, suggesting that neurological alterations manifest themselves in the more advanced stages of the disease (57).

Myocarditis with intense diffuse mononuclear cell infiltrate mainly affecting the right ventricle and right atrium, and the presence of degenerated cardiac fibers with an aspect similar to that of chagasic myocarditis, have been described in dogs (57). Although there are few reports of cardiac lesions with $T$. evansi infection, specifically in the case of myocarditis (excluding myositis), such lesions are frequently associated with trypanosomiasis. The etiology of these lesions in domestic animals is unknown, but there are strong suspicions that these alterations are a consequence of antigen-antibody interaction and the deposition of these complexes in cardiac muscle cells (60).

\section{DIAGNOSIS}

\section{Clinical}

Due to the multisystemic nature of trypanosomiasis, the variety of clinical signs, and the indeterminate character of chronic Chagas disease, diagnosis can be missed. The evidence of abnormal cardiac rhythms and congestive cardiac insufficiency with right ventricle dysfunction justifies investigation for chagasic myocarditis (11). In dogs, the clinical pathological aspects of the disease are unspecific and do not assist in diagnosis (54). However, diagnosis can be based on findings of congestive 
cardiac insufficiency associated with a history suggestive of having been in zones where trypanosomiasis is endemic, and on laboratory exam results (4).

\section{Laboratory}

The acute phase of Chagas disease in dogs can be diagnosed by direct demonstration of the presence of trypomastigote forms in the blood, by a blood smear stained by the Giemsa method, or by a thick smear (4).

Currently, the direct detection of $T$. evansi is usually performed by microscopic examination of fresh blood between a slide and coverslip, by blood smear, or even by using centrifuge methods that concentrate parasites for later viewing. Such techniques include searching for the parasite in leukocyte aggregations, the microhematocrit method (MHCT), the Strout concentration method, and others (4).

The recognized isolation method in specific culture medium uses liver infusion tryptose (LIT), which is incubated at $28^{\circ} \mathrm{C}$ for a few days, allowing epimastigote forms to appear as multiplication takes place (4).

The biological test consists of an indirect parasitological method that can also be used to detect $T$. evansi and $T$. cruzi; in this method, suspect blood is inoculated into susceptible laboratory animals, increasing the chance of parasite detection (4). Intraperitoneal injections of mice with $2 \mathrm{~mL}$ suspect blood or cephalorachidian liquid is used to evaluate the presence of trypomastigotes in the mice's blood after one week; several follow-up observations are made for up to two months to decide whether the result is positive or not $(4,61)$.

Although conclusive diagnosis of infection can be established by demonstrating the presence of parasites, parasitological methods have poor sensitivity. The fluctuating character of parasitemia and the very low number of circulating parasites, especially in the chronic infection stage, frequently impede their detection, even with the use of concentration and inoculation methods in suspect animals. The reliability of parasitological methods is questionable for naturally occurring cases, in which parasitemia is often low and sporadic. Alternative methods that provide indirect evidence of $T$. evansi infection, such as antibody or antigen detection techniques, have been developed and have assumed a great degree of importance in the diagnosis of this trypanosomiasis (42).

The indirect immunoflorescence reaction (IIFR) is considered the reference serological test for $T$. cruzi trypanosomiasis. It detects the presence of anti- $T$. cruzi 
IgG antibodies and is based on epimastigote forms of the parasite. ELISA and hemagglutination tests are also used $(4,62)$. The polymerase chain reaction (PCR) is used to amplify fractions of the protozoan's DNA, which are then used to identify it. The reported high sensitivity and specificity of PCR have increased its diagnostic potential. Using two of the cited techniques allows reliable diagnosis in most cases (4).

In contrast to the already cited limitations in parasitological diagnosis, serological diagnosis is facilitated by the presence of many early and apparently constant anti- $T$. evansi and anti-T. cruzi antibodies during the course of infection. Various antibody detection techniques have been studied to diagnose $T$. evansi in different hosts; these techniques include hemagglutination, direct agglutination, and complement fixation (42). However, IIFR and ELISA (Ac-ELISA) have shown more sensitivity and higher diagnostic value than all of the techniques developed earlier. IIFR showed $100 \%$ sensitivity in experimentally infected dogs (57).

Antibody detection immunodiagnosis techniques, although they have much higher sensitivity than parasitological techniques, reflect host exposure to the parasite, but do not necessarily indicate the presence of active infection. Studies have shown that antibodies remain in the bloodstream for more than 100 days after treatment and the elimination of infection; this can imply interpretation problems in these assays, which would impede the determination of infection status in each animal. In this respect, using ELISA for the detection of antigens is superior to the ELISA antibody test, as studies have shown that the antigen ELISA test detected infection before the antibody ELISA did; after treatment, antigen ELISA values quickly decreased to preinfection levels. It also appears that the antigen test is able to identify animals with patently active infection. However, it is less sensitive than the antibody ELISA (42). In relation to specificity, it is known that serological methods for both antibody and antigen detection present problems due to cross-reactivity with other trypanosome species, such as $T$. rangeli, or even with other trypanosomatid genera, such as Leishmania $(42,63)$.

With the introduction of molecular diagnosis techniques, various assays have been developed based on DNA detection by PCR, and this technique has proved more sensitive than conventional parasitological methods in diagnosing various trypanosome species in different hosts. However, its high cost and complexity are still drawbacks to its routine use in diagnosis (42). 
Another difficulty related to canine trypanosomiasis is the differential diagnosis between $T$. cruzi and $T$. rangeli. Although Trypanosoma rangeli is not pathogenic in humans or dogs, its medical and epidemiological importance resides in the fact that it shares vectors, reservoirs, and geographical areas with Trypanosoma cruzi. T. rangeli can induce immune response and cross-reactivity with $T$. cruzi, which is a barrier in serological diagnosis of Chagas disease in areas where these parasites coexist (42). T. rangeli and $T$. cruzi are protozoan parasites that are found in the same wild and domestic hosts (including humans) and in the same insect vectors (kissing bugs) in Latin American countries. P35 and P36 indicators were originally designed for the amplification of the $T$. cruzi kDNA minicycle and have been used to evaluate treatment etiology of Chagas disease in countries like Bolivia, and in areas of Brazil where $T$. rangeli has still not been reported in humans $(64,65)$. However, the use of these indicators in countries where mixed $T$. cruzi and $T$. rangeli infections are present in vectors and vertebrate hosts makes diagnosis more complicated because the amplification profile seen depends on the proportion of parasites found in the blood sample or intestines of the vector, as one species can mask the other $(65,66)$. The 330-base pair fragment of $T$. cruzi migrates very near to the 300-base pair fragment of $T$. rangeli, and the proximity of these two fragments in an agarose gel can create difficulties for specific diagnoses in mixed infections, because the detection of typical $T$. rangeli bands does not allow for the visualization of the coexistent $T$. cruzi infection (65).

In experimental studies, the identification of individual $T$. cruzi or $T$. rangeli infections in Rhodnius prolixus was easily performed by PCR of kDNA using P35/P36 indicators in hemolymph saliva glands or intestinal tissue, with the profiling for each parasite being possible only with a polyacrylamide gel (65).

Pavia et al. (67) used two types of PCR amplification: TcH2AF/R for the histone gene H2A/SIRE, and TrFR2 for a repetitive gene of $\mathrm{Cl} 1$ nucleolar RNA (sno-RNA-Cl1). Both PCR P35/P36 reactions could correctly detect the presence of $T$. cruzi or $T$. rangeli in experimentally infected triatomines.

With respect to blood culture, the use of LIT medium (Liver Infusion Tryptose) at 26$28^{\circ} \mathrm{C}$ favors the development of not just $T$. cruzi, but also all trypanosomes whose multiplication occurs in the rear part of the triatomine vector, as in the case of $T$. rangeli (22). Lucheis et al. (34) obtained $60 \%$ positivity to hemoculture in LIT medium when using blood samples from dogs owned by chronic Chagas disease patients 
from Botucatu city (São Paulo state, Brazil) and the surrounding region. The fact that this followed a marked improvement in the technique was confirmed by some studies in which the animals had much higher parasitemia levels than their owners, thus facilitating trypanosome isolation in specific media (68).

\section{TREATMENT}

There are few studies on drug treatment efficacy in surra, especially in dogs. Diminazene aceturate has been shown to be an effective treatment for $T$. evansi in this species, as it presents a higher therapeutic index than other drugs, in addition to a low incidence of resistance (9). In another experiment, subcutaneous treatment with this drug was successful in a naturally infected dog at a dose of $7 \mathrm{mg} / \mathrm{kg}$ on the first day and $3.5 \mathrm{mg} / \mathrm{kg}$ on the following day (42).

In a study by Silva et al. (69), diminazene aceturate was only effective in controlling trypanosomiasis caused by $T$. evansi in Rattus norvegicus, after use for five consecutive days. In contrast, imidocarb diproprionate was not effective in controlling this illness at any dose. None of the medications used caused hepatic or renal lesions in the treated animals. Doyle (9) had already reported in 2006 that, despite the effectiveness of diminazene aceturate in treating Wistar rats (Rattus norvegicus) experimentally infected with $T$. evansi, the disease recurred.

The treatment of Chagas disease in dogs is still difficult, as the disease does not permit a definitive cure. Treatment is often prolonged, but offers a reasonable quality of life $(4,63)$.

Benzonidazole (nitroimidazole), when tested in dogs, produces neurological outcomes such as: apathy, hypertonia and hypereflexia of the hind limbs, and loss of balance. In the USA, another drug, nifurtimox (5-nitrofuran) has been used for 30 to 60 days, but its side effects (neurological and gastrointestinal) were also serious (54).

\section{PROPHYLAXIS}

Control is mainly based on measures related to impeding vector proliferation. In addition to specific measures such as serological and entomological studies and awareness campaigns, health education activities must be included in all control activities. The care and attention taken with diagnosis in the acute phase, both in humans and in animals, and initiatives to make communities from endemic areas 
aware and explain to them the nature of the disease are vital for disease control and prevention (70).

In a study by Basso et al. (70), dogs of undefined breeds received three doses of subcutaneous injections of $T$. rangeli epimastigote forms at six-week intervals. This procedure induced the development of anti-T. cruzi antibodies. Whereas both control and immunized groups developed detectable parasitemia, this parasitemia was less severe and of shorter duration in vaccinated animals. Curiously, feeding Triatoma infestans nymphs with the blood of vaccinated chronically infected dogs led to an accentuated reduction in the vector infection rate. These results suggest that vectoral parasitemia can be reduced by vaccinating dogs. However, until now, there has been no sufficiently effective safe vaccine and systemic action against the reservoirs is not recommended (4).

\section{FINAL CONSIDERATIONS}

Of all domestic animals, dogs are very important reservoirs in the transmission of trypanosomatids, especially Trypanosoma cruzi, the causal agent of Chagas disease. As dogs have a close relationship with humans, they assume substantial epidemiological importance in the context of this zoonosis, and consequently for public health. Similar to what occurs in humans, this species can develop chronic pathological alterations, including congestive cardiac insufficiency, but due to the multisystemic nature of the infection, diagnosis becomes difficult and can be missed; this raises the need for mainly epidemiological and clinical support. Moreover, etiology must be confirmed by laboratory diagnosis, which can provide important support when using appropriate techniques, adequate reagents, and following good laboratory practices. 


\section{REFERENCES}

1. Jones TC, Hunt RD, King NW. Moléstias causadas por protozoários. In: Jones TC, Hunt RD, King NW, editors. Patologia veterinária. $6^{\text {th }}$ ed. São Paulo: Manole; 2000. p. 559-610.

2. Gomes AH, Ferreira IM, Lima ML, Cunha EA, Garcia AS, Araújo MF, et al. PCR identification of leishmania in diagnosis and control of canine leishmaniasis. Vet Parasitol. 2007;144(3-4):234-41.

3. Rosypal AC, Cortés-Vecino JA, Gennari SM, Dubey JP, Tidwell RR, Lindsay DS, et al. Serological survey of Leishmania infantum and Trypanosoma cruzi in dogs from urban areas of Brazil and Colombia. Vet Parasitol. 2007;149(3-4):172-7.

4. Amóra SSA. Epidemiologia da leishmaniose e tripanossomíase canina no município de Mossoró [master's thesis]. Fortaleza: Faculdade de Veterinária da Universidade Estadual do Ceará; 2004. 90 p.

5. Maywald PG, Machado MI, Costa-Cruz JM, Gonçalves-Pires MRF. Leishmaniose tegumentar, visceral e doença de Chagas caninas em municípios do Triângulo Mineiro e Alto Paranaíba, Minas Gerais, Brasil. Cad Saúde Pública 1996;12(3):3218.

6. Dias JC, Silveira AC, Schofield CJ. The impact of Chagas disease control in Latin America: a review. Mem Inst Oswaldo Cruz. 2002;97(5):603-12.

7. Josh PP, Shegokar VR, Powar RM, Herder S, Katti R, Salkar HR, et al. Human trypanosomiasis caused by Trypanosoma evansi in India: the first case report. Am J Trop Med Hyg. 2005;73(3):491-5.

8. Josh PP, Chaudharib A, Shegokarc VR, Powarc RM, Dania VS, Somalwara AM, et al. Treatment and follow-up of the first case of human trypanosomiasis caused by Trypanosoma evansi in India. Trans R Soc Trop Med Hyg. 2006;100(1):989-91.

9. Doyle RL. Eficácia de três medicamentos no controle da infecção experimental por Trypanosoma evansi em ratos (Rattus norvegicus) linhagem Wistar. [Master's Thesis]. Santa Maria: Centro de Ciências Rurais da Universidade Federal de Santa Maria; 2006. 40 p.

10. Gurtler RE, Cecere MC, Lauricella MA, Cardinal MV, Kitron U, Cohen JE. Domestic dogs and cats as source of Trypanosoma cruzi infection in rural northwestern Argentina. Parasitology. 2007;134(Pt 1):69-82. 
11. Souza Al, Paulino-Junior D, Sousa MG, Camacho AA. Aspectos clínicolaboratoriais da infecção natural por Trypanosoma cruzi em cães de Mato Grosso do Sul. Ciênc Rur. 2008;38(5):1351-6.

12. Veronesi R, Focaccia R. Tratado de Infectologia. $2^{\text {nd }}$ ed. São Paulo: Atheneu; 2002. p. 1007-23.

13. Dias JCP, Machado EMM, Fernandes AL, Vinhares MC. Esboço geral e perspectivas da doença de Chagas no Nordeste do Brasil. Cad Saúde Pública. 2000; 16(2):13-34.

14. Alencar, JE. História natural da doença de Chagas no Estado do Ceará. Fortaleza: Imprensa Universitária, Universidade Federal do Ceará; 1987. 341 p.

15. de Souza W. O parasito e sua interação com os hospedeiros. In: Trypanosoma cruzi e doença de Chagas. $2^{\text {nd }}$ ed. Rio de Janeiro: Guanabara Koogan; 2000. p. 88126.

16. Herrera HM, Norek A, Freitas TPT, Rademaker V, Fernandes O, Jansen AM, et al. Domestic and wild mammals infection by Trypanosoma evansi in a pristine area of the Brazilian Pantanal region. Parasitol Res. 2005;96(2):121-6.

17. Deane LM. Animal reservoirs of Trypanosoma cruzi in Brazil. Rev Bras Malar D Trop. 1964;16(1):27-48.

18 Montenegro VM, Jiménez M, Dias JC, Zeledón R. Chagas disease in dogs from endemic areas of Costa Rica. Mem Inst Oswaldo Cruz. 2002;97(4):491-4.

19. Beard CB, Pye G, Steurer FJ, Rodriguez R, Campman R, Peterson AT, et al. Chagas disease in a domestic transmission cycle, southern Texas, USA. Emerg Infect Dis. 2003;9(1):103-5.

20. Pífano F, Peñalver LM, Medina R, Dominguez E. La infección natural del perro por el Trypanosoma rangeli. Primera comprobación de un reservorio vertebrado extra-humano de protozoario de la natureza. Gac Med Car. 1948;56(1):7.

21. D'alessandro A. Biology of Trypanosoma (Herpetosoma) rangeli, Tejera, 1920. In: Lumsden WHR, Evans DA, editors. The biology of the kinetoplastida. New York: Academic Press; 1976. p. 327-403.

22. Hoare CA. The trypanosomes of mammals: a zoological monograph. Oxford: Blackwell Scientific Publications; 1972. p. 288-313.

23. Kaggwa E, Munyua WK, Mugera GM. The pathogenicity of Trypanosoma brucei brucei in dogs. Bull Anim Heal Prod Africa. 1984;82(1):360-8. 
24. Harrus S, Harmelin A, Presenty B, Bark H. Trypanosoma congolense infection in two dogs. J Smal Anim Prac. 1995;36(2):83-6.

25. Franke $\mathrm{CR}$, Greiner $\mathrm{M}$, Mehlitz D. Investigation on naturally occurring Trypanosoma evansi infections in horses, cattle, dogs and capybaras (Hydrochaerishydrochaeris) in Pantanal de Poconé (Mato Grosso, Brazil). Acta Trop. 1994;58(2):159-69.

26. Savani ES, Nunes VL, Galati EA, Castilho TM, Araújo FS, Ilha IMN, et al. Occurrence of co-infection by Leishmania (Leishmania) chagasi and Trypanosoma (Trypanozoon) evansi in a dog in the State of Mato Grosso do Sul, Brazil. Mem Inst Oswaldo Cruz. 2005;100(7):739-41.

27. Bastrenta B, Mita N, Buitargo R, Vargas F, Flores M, Machane M, et al. Human mixed infections of Leishmania spp. and Leishmania-Trypanosoma cruzi in a Sub Andean Bolivian Area: identification by polymerase chain reaction/hybridization and isoenzyme. Mem Inst Oswaldo Cruz. 2003;98(2):255-64.

28. Madeira MF, Schubach A, Schubach TM, Pacheco RS, Oliveira FS, Figueiredo FB. Co-infecção natural por Leishmania (Viannia) braziliensis e Trypanosoma sp. em cão doméstico. In: XL Congresso da Sociedade Brasileira de Medicina Tropical, 2004, Aracaju, Brazil. Rev Soc Bras Med Trop; 2004. 287 p.

29. Madeira MF, Schubach AO, Schubach TMP, Pacheco RS, Oliveira FS, Pereira $\mathrm{SA}$, et al. Mixed infection with Leishmania (Viannia) braziliensis and Leishmania (Leishmania) chagasi in a naturally infected dog from Rio de Janeiro, Brazil. Trans Roy Soc Trop Med Hyg. 2006;100(5):442-5.

30. Acha PN, Szyfres B. Zoonosis parasitarias. In: Acha PN, Szyfres B. Zoonosis y enfermidades transmisibles comunes al hombre y a los animales. $3^{\text {rd }}$ ed. Washington: Organización Panamericana de La Salud; 2003. p. 374-82.

31. Andrade ES. Infecções causadas por hematozoários em cães e gatos de ocorrência no Brasil: semelhanças e particularidades. [Master's Thesis]. Porto Alegre: Faculdade de Veterinária da Universidade Federal do Rio Grande do Sul; 2007. 98 p.

32. Dantas-Torres F. Canine vector-borne diseases in Brazil. Parasit Vectors. 2008;1(1):25.

33. Ramirez LE, Machado MI, Maywald PG, Matos A, Chiari E, Lages-Silva EL. Primeira evidência de Trypanosoma rangeli no sudeste do Brasil, região endêmica para doença de Chagas. Rev Soc Bras Med Trop. 1998;31(1):99-102. 
34. Lucheis SB, Da Silva AV, Araújo Jr. JP, Langoni H, Meira DA, MarcondesMachado J. Trypanosomatids in dogs belonging to individuals with chronic Chagas disease living in Botucatu town and surrounding region. São Paulo State, Brazil. J Venom Anim Toxins incl Trop Dis. 2005;11(4):492-509.

35. Miles MA, Arias JR, Valente SA, Naiff RD, de Souza AA, Povoa MM, et al. Vertebrate hosts and vectors of Trypanosoma rangeli in the Amazon basin of Brazil. Am J Trop Med Hyg. 1983;32(6):1251-9.

36. Maia da Silva FM, Marcili A, Lima L, Cavazzana Jr. M, Ortiz PA, Campaner M, et al. Trypanosoma rangeli isolates of bats from Central Brazil: genotyping, phylogenetic analysis enable description of a new lineage using spliced-leader gene sequences. Acta Trop. 2009;109(3):199-207.

37. Wanderley DMV. Epidemiologia da doença de Chagas. Revista SOCESP.. 1994;4(2):77-84.

38. Sarmento AMC, Guazelli A, Barreto LFG, Costa VM, Hoffmann JL, Lucheis SB, et al. Estudo da leptospirose em cães e gatos, da leishmaniose e da doença de Chagas em cães de aldeias indígenas guaranis em Parelheiros, Município de São Paulo-SP. Vet Zootec. 2007;14(2):193-203.

39. Ribeiro RD, Garcia TAR, Bonoma WC. Contribuição para o estudo dos mecanismos de transmissão do agente etiológico da doença de Chagas. Rev Saúde Públ. 1987;21(1):51-4.

40. Urqhart GM, Armour J, Duncun JL, Dunn AM, Jennings FW. Protozoologia veterinária. In: Urqhat GM, Armour J, Duncun JL, Dunn AM, Jennings FW, editors. Parasitologia veterinária. $2^{\text {nd }}$ ed. Rio de Janeiro: Guanabara Koogan; 1996. 185 p.

41. Rojas A, Vinhães MC, Rodríguez M, Monroy J, Persaud N, Aznar C, et al. Reunião Internacional sobre vigilância e prevenção da doença de Chagas na Amazônia. Implementação da iniciativa intergovernamental de vigilância e prevenção da doença de Chagas na Amazônia. Rev Soc Bras Med Trop. 2005;38(1):82-9.

42. Aquino LPCT. Importância da infecção por Trypanosoma evansi em cães no Brasil; 2007 [updated 2009 March 12; cited 2009 March 13]. Available from: http://www.fav.br/programasinst/Revistas/revistas2007/veterinaria/Importancia da in feccao.pdf.

43. Barr SC, Greene CE, Matete G. Trypanosomiasis. In: Greene CE, editor. Infectious diseases of dog and cat. $3^{\text {rd }}$ ed. St. Louis: Saunders; 2006. p. 445-50. 
44. Brenner Z, Andrade ZA, Barral-Neto M. Epidemiologia. In: Brenner Z, Andrade $Z A$, Barral-Neto M, editors. Trypanosoma cruzi e doença de Chagas. $2^{\text {nd }}$ ed. Rio de Janeiro: Guanabara Koogan; 2000. p. 21-46.

45. Fernandes AJ, Chiari E, Casanova C, Dias JCP, Romanaha AJ. The threat of reintroduction of natural transmission of Chagas disease in Bambuí, Minas Gerais state, Brazil, due to Panstrongylus megistus. Mem Inst Oswaldo Cruz. 1992;87(2): 285-9.

46. Zeledón R. Epidemiology, modes of transmission and reservoir of Chagas disease. Ciba Foundation Symposium. 1974;20:51-7.

47. Greene CE, editor. Infectious diseases of the dog and cat. $2^{\text {nd }}$ ed. Philadelphia: Saunders W.B.; 1998. 934 p.

48. Franciscato C, Lopes STA, Teixeira MMG, Monteiro SG, Wolkmer P, Garmatz BC, et al. Cão naturalmente infectado por Trypanosoma evansi em Santa Maria, RS, Brasil. Ciênc Rur. 2007;37(1):288-91.

49. Madeira MF, Sousa MA, Barros JH, Figueiredo FB, Fagundes A, Schubach A, et al. Trypanosoma caninum n. sp. (Protozo: Kinetoplastida) isolated from intact skin of a domestic dog (Canis familiaris) captured in Rio de Janeiro, Brazil. Parasitology. 2009;136(4):411-23.

50. Scalabrini A, Cardoso A, Andrade SG, Andrade ZA. Correlação clínico-patológica na forma indeterminada da doença de Chagas experimental do cão. Arq Bras Cardiol. 1996;67(6):385-8.

51. Caliari MV, Machado RP, Lana M, Cajá RAF, Carneiro CM, Bahia MT, et al. Quantitative analysis of cardiac lesions in chronic canine chagasic cardiomyopathy. Rev Inst Med Trop São Paulo. 2002;44(5):273-8.

52. Pascon JPE. Avaliação clínica da cardiomiopatia chagásica crônica em cães. [Master's Thesis]. Jaboticabal: Faculdades de Ciências Agrárias e Veterinárias da Universidade Estadual Paulista; 2007. 85 p.

53. Teixeira ARL, Cunha Neto E, Rizzo LV, Silva R. Trypanocidal nitroarene treatment of experimental Trypanosoma cruzi infection does not prevent progression of chronic-phase heart lesions in rabbits. J infect Dis. 1990;162(6):1420.

54. Ettinger SJ, Feldman EC. Tratado de medicina veterinária interna - moléstias do cão e do gato. $4^{\text {th }}$ ed. São Paulo: Manole; 1997. 2930 p. 2 vol. 
55. Rossi MA. Fibrosis and inflammatory cells in human chronic chagasic myocarditis: scanning electron microscopy and immunohistochemical observations. Int J Cardiol. 1998;66(2):183-94.

56. Barr SC, Gossett KA, Klei TR. Clinical, clinicopathologic, and parasitologic observation of trypanosomiasis in dog infected with North American Trypanosoma cruzi isolates. Am J Vet Res. 1991;52(6):954-60.

57. Aquino LPCT, Machado RZ, Alessi AC, Santana AE, Castro MB, Marques LC, et al. Hematological, biochemical and anatomopathological aspects of experimental infection with Trypanosoma evansi in dogs. Arq Bras Med Vet Zootec. 2002;54(1):818.

58. Aquino LPCT. Aspectos clínicos, imunológicos e patológicos da infecção experimental em cães por Trypanosoma evansi. [Master's Thesis]. Jaboticabal: Faculdade de Ciências Agrárias e Veterinárias da Universidade Estadual Paulista; 1997. 93 p.

59. Sandoval GL, Coppo NB, Negrette, MS. Alterações bioquímicas e histopatológicas de um cão e ratos infectados com Trypanosoma evansi. Hora Vet. 1994;14(81):53-5.

60. Urqhart GM, Holmes PH. African Trypanosomiasis. In: Soulsby EJL. Immune responses in parasitic infections: immunology, immunopathology and immunoprophylaxis. Boca Raton: CRC Press; 1987. p. 1-23.

61. Gonçalves da Costa SC. Estudo sobre a tripanossomíase canina; 2002 [updated 2009 March 19; cited 2009 March 20]. Available from: http://www.ioclchagaslepidemiologialepidemiologla.htm

62. Camacho AA. Cardiomiopatia chagásica em cães. In: Belerenian GC, Mucha CJ, Camacho AA. Afecções cardiovasculares em pequenos animais. São Paulo: Interbook; 2003. p. 162-5.

63. Desquenes M, Bengaly Z, Millogo L, Meme Y, Sakande H. The analysis of the cross-reactions occurring in antibody-ELISA for the detection of trypanosomes can improve identification of the parasite species involved. Annal Trop Med Parasitol. 2001;95(2):141-55.

64. Sturm NR, Degrave W, Morel C, Simpson L. Sensitive detection and schizodeme classification of Trypanosoma cruzi cells by amplification of kinetoplast minicircle DNA sequences: use in diagnosis of Chagas' disease. Mol Biochem Parasitol. 1989; 33(3):205-14. 
65. Vallejo GA, Guhl F, Chiari E, Macedo AM. Species specific detection of Trypanosoma cruzi and Trypanosoma rangeli in vector and mammalian hosts by polymerase chain reaction amplification of kinetoplast minicircle DNA. Acta Trop. 1999;72(2):203-12.

66. Vargas N, Souto RP, Carranza JC, Vallejo GA, Zingales B. Amplification of a specific repetitive DNA sequence for Trypanosoma rangeli identification and its potential application in epidemiological investigations. Exp Parasitol. 2000;96(3): 147-59.

67. Pavia PX, Vallejo GA, Montilla M, Nicholls RS, Puerta CJ. Detecção da infecção por Trypanosoma cruzi e Trypanosoma rangeli em vetores triatomíneos através da amplificação dos genes de histona H2A/SIRE e sno-RNA-C11. Rev Inst Med Trop São Paulo. 2007;49(1):23-30.

68. Gurtler RE, Cécere MC, Petersen RM, Rubel DN, Schweigmann NJ. Chagas disease in north-west Argentina: association between Trypanosoma cruzi parasitemia in dogs and cats and infection rates in domestic Triatoma infestans. Trans Roy Soc Trop Med Hyg. 1993;87(1):12-25.

69. Silva AS, Tochetto C, Zanette RA, Pierezan F, Rissi DR, Santurio JM, et al. Aceturato de diminazeno e dipropionato de imidocarb no controle de infecção por Trypanosoma evansi em Rattus norvegicus infectados experimentalmente. Ciênc Rur. 2008;38(5):1357-62.

70. Basso B, Castro I, Introini V, Gil P, Truyens C, Moretti E. Vaccination with Trypanosoma rangeli reduces the infectiousness of dogs experimentally infected with Trypanosoma cruzi. Vaccine. 2007;25(19):3855-8. 